\title{
Long-Lasting Challenge With Public School Evaluation Policy in Georgia
}

\author{
Maka Kordzadze \\ Correspondence: Maka Kordzadze, Administration Department, Ilia State University, Cholokashvili 3/5, 0162, Tbilisi, \\ Georgia. E-mail: maka.kordzadze@iliauni.edu.ge
}

Received: July 9, 2020 Accepted: August 11, 2020 Online Published: August 18, 2020

doi:10.5539/res.v12n3p57

URL: https://doi.org/10.5539/res.v12n3p57

\begin{abstract}
The aspiration of Georgia to become the EU member supported introduction of European guiding principles and systems in education policy, including, the systems of education quality assurance in the country. In $2005-2011$, the evaluation mechanisms of educational institutions of all three levels - high, vocational and general educational institutions got gradually activated. However, evaluation of quality of only private general educational institutions started. As for public schools, the process got postponed four times. The last one is reported by 2026-2027. Almost $90 \%$ of pupils in Georgia studies at public schools, therefore, it can be stated that, overall, the quality evaluation policy of schools in the country is facing serious challenges, which cannot be solved yet. The article discusses those problems of the policy of school quality evaluation, which prevent starting of evaluating public schools and relevant ways of solving them are offered.
\end{abstract}

Keywords: education quality, school evaluation, general education

\section{Introduction}

The importance of proper functioning of education quality assurance systems is especially stressed in European guiding and recommendation documents of education policy, including, general education, which serves as the basis for the education system, "developing strong quality assurance systems is crucial to ensuring all students in schools throughout Europe receive a high-quality education" (Publications Office of the EU, 2018). The recommendation is given in the same document for the countries to have "quality assurance strategies in place which are based on an integrated consideration of each of the six areas of policy and practice and are compatible with the shared European vision" (Publications Office of the EU, 2018). 2 out of 6 areas of policy indicated apply to general education institutions evaluation policy and practice external evaluation of schoold and their self-evaluation (Publications Office of the EU, 2018). Naturally, ensuring effective mechanisms of school evaluation is the priority issue of the general education quality assusrance policy of Georgia. However, problems are as well reported in this direction which have not been managed to be solved for years.

Georgia has made significant steps with the view of harmonizing the country's educational system with those of EU countries. In 2005 the country joined the Bologna Process. Education quality assurance systems were designed. Mechanisms of evaluation and monitoring of educational institutions were developed and activated. Institutional accreditation and authorization of educational institutions got defined as such mechanisms and became obligatory for the educational institutions of all levels (i.e. general, vocational and higher). In 2005-2010 the process of institutional accreditation started to be implemented gradually for public and private higher and vocational educational institutions and in 2010 got replaced by the process of authorization with the same content. However, it was not possible to activate fully mechanisms of evaluation of general educational institutions. Authorization of only private schools started from 2011 whereas that of public ones was postponed several times and has not yet been carried out. Necessity of starting authorization of public schools was strictly stressed in the 2019 review of Organisation for Economic Co-operation and Development (OECD) on evaluation and assessment of education in Georgia: "The review team recommends that Georgia focus its attentions on its original aim to authorize all public schools in the short term, which will help to address the significant gap in school oversight that currently exists" (Ruochen \& Others, 2019). Despite this, the process of authorization of public schools was just postponed again in March 2020 until 2026-2027.

The public sector occupies a main part in the general education system in Georgia, $89.4 \%$ of pupils study at the public schools (National Statistics Office of Georgia, 2020). Therefore, the system of school quality evaluation, which does not involve public schools, will not be able to reflect the real situation in Georgian schools and fails to fulfil its direct function to support imporvement of general education in the country. The fact that the quality needs to be improved is proven by unsatisfactory results of Georgian schoolchildren in international student assessments: Programme for International Student Assessment (PISA), Progress in International Reading Literacy Study (PIRLS), Trends in International Mathematics and Science Study (TIMSS). "According to international estimates, the average indicators of Georgian 
pupils are still behind the average international indicator" (Ministry of Education and Science of Georgia, 2017);

Despite actual problems in respect with the quality of general education and expert recommendations regarding the necessity of starting evaluation of public schools, mechanism of evaluation of public schools could not be activated for years. This indicates significant problems in the area of school evaluation and serves as the most serious challenge for respective policy. Suspending the process of authorization is argumentated every time by the fact that schools should be better prepared for this process whereas preparation envisages making school infrastructure organized, introducing new and modern methods in the process of learning and teaching, etc. Of course, preparing schools in this way is good and essential; however, the reason of holding public school evaluation should be found somewhere else. On the basis of investigation and analysis of relevant local and international official policy documents, the article claims that the response to the mentioned challenge of the school evaluation policy requires the change of the acting model of school evaluation. The article also contains recommendations regarding this change.

\section{Georgian Policy Documents on School Evaluation - Where Is the Problem Hidden?}

Evaluation of school quality, as one of the priority directions of general education quality assurance policy, was planned at the initial stage of the general education reform in Georgia. The main document defining policy in this field is the law of Georgia on general education. Quality control mechanisms of general educational institutions were first reflected in the law in 2005. According to the law, in order to ensure state recognition of education programs implemented by general educational institutions, it was essential to go through respective accreditation on the basis of the rule defined by the legislation and the state only recognized the general education diploma issued by the accredited general education institution (Ministry of Education and Science of Georgia, 2005). The intention to start the school evaluation process was clearly identified in the education consolidated strategy and action plan for 2007-20011. "The MoES will evaluate the compliance of learning process and outcomes with national curricula and development standards through a general school accreditation process carried out by the National Accreditation Center of Georgia" (Ministry of Education and Science of Georgia, 2005). However, this point of the action plan was not met - in 2009 the amendment was made in the law regarding accreditation terms to make general schools considered accredited before the start of 2013-2014 academic year instead of 2010-2011.

In the same period one fact remained out of attention: in 2008, foreign experts Klaus Vittkuhn and Monique Mueller indicated significant problems of vision reflected in the law on school accreditation in the final report of the external assessment of the national center of education accreditation - the state structure managing the process of accreditation (National Education Accreditation Centre, 2008). To be more specific,the following was mentioned in the experts' report: if the Georgian plan of general education quality evaluation was compared with the European Union (EU) practice, we would see that the existing vision, namely, repeated demand of gaining the status for already established schools, did not correspond with the modern best practices.

Indeed, obligatory compliance of this record in law connected with accreditation in respect with public schools created obvious deadlock. In Georgia these days there are 2086 public and 227 private schools (National Statistics Office of Georgia, 2020). Practically, all public schools have been functioning since soviet times and count 50 and more years of operating. Schools in cities were initially placed on the basis of a certain territorial principle in accordance with the so-called service radius of schools - 500-800 meters. Therefore, the public schools used to operate in all territorial units of each city in which children of the school age of this territorial unit used to study with a very small exception. This is the case today as well. Main focus is made on the so-called district public schools since based on the economic condition of the country, traditions, infrastructural and territorial peculiarities, for the majority of population, especially at the primary and basic level of education, it is most convenient and available to apply to the public school which is the closest - the child will get to school in a short period of time, not need any transport and studying is free of charge.

As for the public schools in villages and high mountain regions, the choice of parents there as well naturally falls on nearby public schools. Based on this fact, the legislative outcome defined by the legislation of school quality evaluation, which obliges the general school to gain the status of the school again, i.e. authorization so that to have the right to issue the general education diploma seems to be nonsense? General education at the initial and basic levels is obligatory and the right guaranteed by the constitution, moreover "the state shall ensure the right of each pupil (including pupils with special educational needs) to acquire general education in the official, or in his/her native language as close to his/her place of residence as possible" (Ministry of Education and Science of Georgia, 2010). Restricting the right to issue the general education diploma for the school which is the closest and most available for the population means additional problem for it to get guaranteed education. The problem is not solved by moving the students to other authorized public schools except the fact that pupils will have to walk long distances to school. Public schools being overloaded anyway are not be able to get additional students and even if they do so, it will lead to overloaded classrooms, create the problem of the lack of infrastructure and learning resources, which will worsen the quality of this school. As for the villages and high 
mountainous regions, as it was mentioned before, restricting the issuance of the school diploma does not leave any choice to the local population to move to another school simply because of not having another school.

The law of Georgia on general education underwent through a number of changes in further years. In the 2010 version the new term appeared in law instead of school accreditation - school authorization, which is defined as follows: "Authorisation - the procedure for acquiring the status of a general education institution, which is intended to ensure meeting standards necessary for implementation of appropriate activities to issue an educational document recognized by state" (Ministry of Education and Science of Georgia, 2010). As it can be seen, the term changed, however, the vision related with the external evaluation of schools and the legislative outcome remained the same together with the daedlock. The process of authrisation of public schools themselves was postponed again, first until 2015-2016, then 2020-2021 and finally in March of the current year - until 2026-2027. Whereas further substantial change was not made in the law related with outside view and legislative outcomes.

The explanatory note of final postponing of the process of authorization states that it is purposeful to start the process of authorization of public schools stage-by-stage, in parallel with the process of rehabilitation of public schools so that to decrease to minimum the circumstances preventing meeting the standards of authorization. Indeed, despite substantial progress towards school rehabilitation, still the number of schools is quite high in which the infrastructure and resources are still a painful problem. The public defender's report of 2017 states that "equipping science classrooms and sports halls and operating canteens remain unsolved. This problem is even more acute in public schools of mountainous regions and villages, where canteens are often inoperative and science classrooms and sports halls need rehabilitation and renewal" (Public Defender of Georgia, 2017). It appears that the model of school evaluation selected as of today, confronts the country with the following dilemma for years as well: how should the public school "be punished' because it cannot meet the standards in respect with infrastructure and various resources which the government is itself responsible to ensure?

There may be several challenges in Georgia facing the policy of public- school evaluation. However, one of the main problems is the model of school authorization operating on nowadays. This model, its visions and legislative outcomes fail to meet the requirements of the country and the real situation and, actually, get to the deadlock. The aim of school evaluation mechanisms is not to create additional problems in getting quality education by the pupils but to solve them. To what extent does the existing model of school evaluation correspond with international recommendations and best practices of European countries?

\section{Solving the Problem Requires Shifting From Authorization to a New Model of School Evaluation}

Models of school evaluation are varied in European countries. Each country selects its own model from its culture, traditions, economic opportunities. However, at the same time all these models are based on mutually shared and recognized principles. Most European countries have created frameworks that integrate some combination of internal and external quality assurance mechanisms, which may include: Inspectorates; National student assessments; School self-evaluation; Teacher appraisal“ (European Commission, 2018). Successful functioning of the general education quality assurance system depends on the efficiency of these separate mechanisms, their synergy as well as complementarity.

International guiding documents which describe models of school evaluation in various countries are systematically published in the Document Library of EU commission. A brief summary of review and analysis results of the whole range of these documents (see, e.g., Eurydice, 2015; Publication Office of European Union, 2015; Publications Office of the European Union, 2018) shows that inspection/external evaluation and self-evaluation of schools are those two approaches which European countries use. Besides, external evaluation is focused on evaluating school activities as one whole on the basis of analyzing various spheres and aspects of functioning. These spheres themselves as well as the aspects may be different in various countries and evaluation models. However, the essence of external evaluation is one in all these models - monitoring and improving of school quality.

Another significant approach of school evaluation, self-evaluation of schools, in most countries is used together with external evaluation, i.e. Complements it (Eurydice, 2015).

If we look at the legislative outcomes of the inspection/external evaluation, ,remedial actions are by far the most common. They aim at addressing weaknesses found or at rectifying breaches in the regulations“ (Eurydice, 2015). The so-called disciplinary measures are rather seldom used. Sometimes, disciplinary measures are used in respect with separate persons, which is expressed by dismissing the school director or, very seldom, any other employees. Such measures are mainly related to legislative violations on behalf of these persons. Disciplinary measures which would limit full functioning of school, legislative basis of its activities, is usually used very rare mostly in separate special cases and even in these cases only after the use of remedial measures are not efficient. It also needs to be stressed here that based on modern approaches, use of such special measures of "punishment" towards schools is not shared: "scholars, educators, and reform advocates are calling for a more meaningful next phase of school accountability, one that promotes continuous support and 
improvement rather than mere compliance and efforts to avoid punishment" (Soung, 2018). Summary of analysis of policy documents also gives ground to ensure the following: despite the fact that approaches and models of general school evaluation in European countries are varied enough, they have not yet realized the vision similar to the model of authorization operating in Georgia today. When evaluating the school quality, EU countries are mainly concentrated on quality assistance and improvement; they do not make authorization of already established schools. If the school has the license of operating, it is required to retain and increase quality according to specific criteria; however, it will not be forced to go through repeated procedures of authorization. Different from the model of school authorization operating in Georgia, which contains granting of the status to the school or saying no to it is actually regarded as the final "verdict", "countries emphasise the importance of seeing evaluation and assessment not as ends in themselves, but instead as important tools for achieving improved student outcomes" (Organization for Economic Co-operation and Development [OECD], 2013).

Apart from the main problem already discussed, regarding the existing model of school authorization, in respect with the vision and legislative outcomes, there are other problems too. For example, the regulation on authorization for general schools as a separate document is not developed. The authorization regulation is one common document for all three level - general, vocational and higher educational institutions. Authorization standards are one and the same as well for all these institutions: educational programs, human resources, material resources. Besides this, before 2013 the body making authorization decision - the authorization board - was one general board for the educational institution of all three levels (i.e. higher, vocational, general). The fact mentioned above indirectly indicate that in the circumstances of the existing model of authorization and regulations, the specific nature of schools, the content is not equally taken into consideration. Problems of standards and procedures of school evaluation should become the subject of further, more detailed discussion. However, some significant problem of standards can be mentioned here. The standards are concentrated on the formal legal procedures more than the content of schools. Furthermore, actually, these standards and criteria in fact are more like checklists; the list of certain documents and services is given in them which need to be proved (National Center for Education Quality Enhancement 2020). Besides, the list is not supported with detailed rubrics of assessment and, therefore, gives the possibility of free interpretation. As a result, the process of authorization which today applies to only private schools sometimes becomes useless there as well. One obvious example of this is as follows: such wood ramps are fixed in some schools today that it is practically impossible to move up them by the wheelchair. When discussing the issue of authorization of these schools, these " ramps" were not indicated to be a drawback in the authorization board protocol. The reason is that during the visit, the expert considered the standard to be satisfied at the factual level and attention was not paid to the quality of complying with the standard, i.e. whether this "met" standard would serve the interests of the pupil. In this case, the expert was free during assessment since s/he did not have any additional obligation which would specifically indicate to describe the quality of compliance with the existing standard.

It also needs to be stated here that the problem of external evaluation of schools is negatively reflected on the implementation of the school self-evaluation. Based on legislation, these two processes are interconnected. Therefore, self-evaluation of schools as a separate form of evaluation is not developed. These days, self-evaluation of schools in the country is only of episodic nature and is not compulsory, "most schools currently view self-evaluation as a compliance exercise rather than a way to improve themselves" (Ruochen \& Others, 2019). Therefore, the situation is created when actually any systemic mechanism of school evaluation and accountability is not actually functioning which is negatively reflected on the school quality as well.

As it seems, the existing model of school authorization not just fails to meet the country specifics and needs, furthermore, it is not in compliance with the modern leading best practices and recommendations of schools' evaluation policy and needs to be changed. "Georgia's most immediate concern is to develop a model of authorisation that can be practically applied to all the country's schools" (Ruochen \& Others, 2019) - this recommendation of OECD experts should not be left without attention as well as the above mentioned one given by the international experts in 2008 about the problem of existing model and vision of school evaluation. However, it would be more specific to state that the most immediate objective of the country's general education system is not to develop the new model of authorization but to shift from authorization to the new and different model of school evaluation and monitoring. This new model should be in compliance with both European recommendations and the needs of the country as well as be efficient and apply to public schools as well.

\section{Suggestions About New Model of School Evaluation}

Thorughout the last 2 decades significant reforms have been made in the general education system of Georgia, including - development of the competence-based national curriculum and the scheme of teacher professional development. The outcome of both of these reforms gets consolidated in school and should be reflected in the improvement of quality of teaching and learning there. At the same time, as it was mentioned above, international research on teaching and learning - PISA, TIMSS, PIRLS, demonstrate that results are not improved for years (National Assessment and 
Evaluation Center [NAEC], 2020). Overall, assessment of reform consequences and identifyibg the problems, improvement of student outcomes require activating one more mechanism - school evaluation and monitoring . „The effective monitoring and evaluation of schools is central to the continuous improvement of student learning: Schools need feedback on their performance to help them identify how to improve their practices; and schools should be accountable for their performance" (Organization for Economic Co-operation and Development [OECD], 2013).

The existing model of school evaluation - authorization which failed to be efficient, should be changed with the new model. The objectives of the new model are to take the system of the existing deadlock, extent it to public schools and in fact support the improvement of the quality of teaching and learning in schools.

If we look at the change of the number of public and private schools in Georgia and the amount of pupils in them accoding to years, which is given is Table 1., we will see that percentage distribution of pupils between public and private schools is practically unchanged (National Statistics Office of Georgia, 2020). Public schools used to and remain to be the main means of getting general education. An insignificant 1-\% rise in private school sector is presumable expressed by the fact that the school quality is relatively more attractive for the population. However, this does not change the overall picture.

Table 1. The Amount of Public and Private Schools and the Number of Pupils in Them

\begin{tabular}{cccccc}
\hline Years & $\begin{array}{c}\text { Public } \\
\text { Schools }\end{array}$ & $\begin{array}{c}\text { Private } \\
\text { Schools }\end{array}$ & $\begin{array}{c}\text { Pupils in public } \\
\text { schools }\end{array}$ & $\begin{array}{c}\text { Pupils in private } \\
\text { schools }\end{array}$ & $\begin{array}{c}\text { Pupils in } \\
\text { Public schools \% }\end{array}$ \\
\hline 2012 & 2084 & 236 & 506659 & 52756 & 90.5 \\
2013 & 2084 & 244 & 501950 & 51066 & 90.7 \\
2014 & 2085 & 246 & 500345 & 53649 & 90.3 \\
2015 & 2085 & 246 & 498873 & 55041 & 90.0 \\
2016 & 2085 & 236 & 508888 & 55841 & 90.1 \\
2017 & 2085 & 226 & 518038 & 57143 & 90.1 \\
2018 & 2085 & 228 & 523958 & 60416 & 89.6 \\
2019 & 2086 & 227 & 530112 & 62771 & 89.4
\end{tabular}

Abolishing the existing legislative regulation which requires gaining the school status or the permit to carry out school activities by the public school again, seems to be the logical way of moving the system out of the deadlock. Public schools have this status for already decades and to restrict it is practically a non-sensible decision apart from separate exceptions justified well. The alternative legislative regulation for gaining the permit for school activities is purposeful to be set in the form of the unlimited licensing which is a tested and truest practice in the country and used to be carried out until 2006. At the same time, the state should define and gradually ensure minimum conditions of licensing, in respect with infrastructure and other resource, for the city, village or high mountainous village public schools.

As for ensuring quality evaluation of public schools by means of the new model and supporting learning and teaching quality improvement in schools, there is extremely fruitful and interesting practice gained in European countries. It is essential to share this practice and adapt it to the specificity of Georgia. One of the widespread and tested practices to be shared is conception of effective schools. It is possible to make sure the new model of school evaluation is based on measuring school effectiveness.

The effective school paradigm has become especially relevant in education quality evaluation approximately from 80ies of the past century. "Identifying effective and ineffective schools is a dominant issue in education in light of the increasing concern for achievement and accountability" (Frederick, 1987). Discussing this issue in the field of education quality evaluation is intensively researched and a lot of practical coursebooks are dedicated to it, according to which the conception of measuring school effectiveness is based on assessing school performance, namely, to what extent the school helps students with various social-economic backgrounds to achieve maximum academic results and how the school uses the resources available to it for this purpose. To measure effectiveness, focus is mainly made on comparing the "output" in the form of students' academic results and the amount "invested" in schools as well as the funding envisaged for each student, qualities of the school's organizational management and strategies of the academic and lesson processes (Scheerens, 2000). The term itself "effective school" is being intensively discussed. However, mostly definition of effective school means the school in which the students' cognitive, psychomotor, social, academic, emotional, moral and asthetic skills are developed, resources are efficiently used and teachers' satisfaction is achieved. This is a school in which students have the optimal environment for self-realization (see, e.g., Goldstein, 1997; Wallin, 2003; Balc1, 2011; Şişman, 2011; İzzet DÖŞ, 2013). 
Why is it purposeful for Georgia to have the school evaluation model based on conception of school effectiveness? According to this conception, evaluating effectiveness of schools is not based on absolute standards as it is envisaged in Georgia these days by the acting decree of authorization. It is rather based on relative standards. This gives the possibility to implement in the country objective evaluation of schools significantly different from each other by the geographical location, infrastructural opportunities and resources and social-economic background of schoolchildren. The model of evaluating school effectiveness is flexible and gives the possibility to adapt to the needs of the specific country and the system. For this purpose, "each system of education needs to conduct its own research into the identification of variables and factors associated with "effectiveness" (Scheerens, 2000). On the basis of the respective research it is possible to select the proper algorithm and variables of measurement adapted to the specificity and the real situation of Georgia.

Mentioning several aspects of the situation in schools of Georgia clearly demonstrates some factors and variables which may be focused on in the model of evaluating effectiveness of schools. For example, the data of city and villages schools in Georgia today are different and results of village schoolchildren in international tests and national exams are much worse (NAEC, 2020). Besides, according to PISA 2015, low social-economic status of schoolchildren in Georgia got the scores less by $78 \%$ compared with those with high social-economic status, which roughly is equal to studyng at school for 2,5 years. This difference is much higher than in Russia (58-point difference) and Turkey (50-point difference) (Ruochen \& Others, 2019). There is evidence of the fact that even among the schools with the same amount of students some schools require almost three times higher funding than others and spends it (Ruochen \& Others, 2019). Lack of teachers in some subjects may be named as the problems of some regional schools. One more negative side which harms less prestigious as well as village schools is a some kind of stigma that these schools are weak, which lowers the motivation as pupils think that they will not be able to obtain good results since they have to study at a "bad" school.

The model based on measuring the effectiveness of schools will make schools motivated and give them the instruments to be fully creative to solve the problems confronting them. For example, village schools are able to use their priority in comparison with city schools that there are less pupils in their classes than in city schools where classes are overcrowded. Therefore, the teacher in village school has the possibility to work more intensively with the pupil individually. Regional schools are able to cooperate with regional universities which are situated in practically all regions of the country, including, state universities. Schools are able to prepare in cooperation with them various projects to improve the quality of teaching and learning of their pupils. These universities have sufficient resources and motivation too to get involved in such projects. In schools in which there is a problem of school teacher deficit, one of the means of taking care of this problem may be to involve more quality online classes in schools. The possibility of quite efficiently conducting such online lessons was clearly identified recently during the COVID-19 epidemic in the circumstances of school quarantine. Schools are able to demonstrate their strong side in respect with efficiently spending funding. The main thing is to make sure that to measure success of various types of schools the approach is differentiated, and all successful steps are assessed respectively. Eventually, evaluation should reveal what kind of positive impact this or that particular school makes on the achievements of its students, to what extent it gives students with different socio-economic backgrounds equal opportunity to fully express their potential, what measures it uses for this and how efficiently it uses in this process its financial as well as material and human resources, what the school does to improve resources and the quality of teaching and learning, What the mechanisms of encouraging and attracting teachers are used and how satisfied teachers are with the school.

The given model of evaluation has the possibility to promote development of schools, increase their motivation to become more effective and "good schools“, provided that the goodness of the schools is measured by its effectiveness. It is possible to identify and encourage the most effective, the so-called "best or successful schools" as a result of the process of evaluation and step-by step to wipe out the stigma of the above-mentioned "bad school". It is possible to make the school evaluation report public so that the specific community of the specific school is aware of successes and real problems of the school situated in it and is involved in solving the latter. Publication of the school evaluation report is quite a widespread practice in European countries. Practically all European Countries, with few exceptions make their final external evaluation reports public or distribute them with certain restrictions (Eurydice. 2020).

The model of school evaluation based on measuring effectiveness of school at the same time will enable the general education system to identify what is happening in public schools of the country, plan the policy of quality improvement of schools. Besides, this model envisages granting more autonomy to schools, necessity of more decentralization of the school system and possibly will initiate positive progress in this regard.

As for the standards and criteria to measure school effectiveness, all interested parties involved in the system of general education should take part in developing them. Open discussions, reviews are essential. However, this should be done in reasonably limited terms. Numerous international recommendations and course books for elaboration of these standards and criteria also exist and it will be essential to use them too. 
In order to make sure that postponing public schools' evaluation is not necessary and already by 2026-2027, or even earlier, the system of school evaluation operates fully, it is purposeful to immediately start preparing the new model of school evaluation. It needs to be taken into consideration at the preparation stage that "the amount of guidance and support that schools receive in self-evaluation and external inspection appears to markedly affect the impact that inspections have on schools" (Whitby, 2010). Therefore, the process of getting ready for evaluation should include equipping external evaluation experts with accurate tools, respective knowledge and skills as well as maximum support of schools to carry out self-evaluation according to the new model, standards and criteria. It is worth noting that the importance of self-evaluation is especially underlined for improving school effectiveness (Scheerens, 2000). Therefore, activating the new model of school evaluation should radically change the reality today, when schools ,receive little support to undertake self-evaluation or to understand its purpose. In many schools, self-evaluation is frequently limited to a cut and paste exercise to meet external requirements“" (Ruochen \& Others, 2019).

To be realistic, despite extremely significant steps in respect with school infrastructure and improvement of resources, the educational system of Georgia may require years before all schools meet standard, similar and desired high requirements. In this period, permanent postponing of public-school evaluation and leaving the system without efficient mechanisms of monitoring and accountability, is unjustified. To prove postponing the process of public-school evaluation, sometimes shortage of cost capacity and respective resources is used as the argument. However, this should not be a proper argument, public schools are funded by the state and it is within the interest of the state to know how efficiently the system works within which it gives funding, where the problem is, what should be corrected and improved. Moreover, "we spend more and more for low quality education" (Namchevadze, 2018). "From 2011 to 2018, the state funding on school education almost doubled in Georgia. Lack of correlation between funding of school education and its quality is caused by nonexistence of proper quality-oriented public policy" (Namchevadze, 2018).

It is not worth to lose the time and wait for "better time". On the contrary, schools should be provided in as much timely manner as possible with evaluation mechanisms which can be activated and used within the existing setting, at unequal initial terms of schools. Mechanisms of evaluation, which will be used to measure school effectiveness, teach schools to achieve maximum best outcome with the existing resources. Stage-by-stage strengthening of public schools with infrastructure, resources, teacher training should serve as the parallel process to this one. When infrastructure and volume and quality of resources of the specific school is improved, effective school will use this increased resources too effectively again. It also should be noted that evaluation of school effectiveness is not a onetime act. It is a periodical and non-stop process and in this process measurement variables of school effectiveness will be periodically reviewed in rapid succession of changing the reality, the standards themselves as well as evaluation instruments will be revised.

\section{Conclusions}

1. The challenge school evaluation policy is facing in Georgia today is to make sure the system of school evaluation is fully operational so that it involves public schools of the country as well and actually support the improvement of quality of learning and teaching in schools;

2. A proper response to this challenge will be to change the existing model of school evaluation - authorization of schools with a new model since the existing model can not meet the needs of the country, is not efficient and the vision on which it is based, is not shared by the modern European recommendations and best practices;

3. The legislative regulation of gaining the status by public schools envisaged by the existing model of authorization, is purposeful to be changed in the new model by the limitless licensing of public schools;

4. The new model of school evaluation may be the one based on measuring school effectiveness which is used to assess how successfully the school manages to assist each pupil in the circumstances of resources within its scope to become fully self-realized and achieve desirable academic outcomes, find out what the school does to advance and improve the quality of learning and teaching;

5. The model of evaluation based on measuring school effectiveness, respective standards and indicators should be developed with the involvement of all interested parties and taking into consideration international recommendations and best practices of European countries;

6. Respective training is necessary for starting the process of evaluation using the new model. At the preparatory stage schools should be provided with assistance to implement self-evaluation in accordance with the new model and standards. In order to make sure that external evaluation reports will be useful feedback to improve the quality of teaching and learning, it is essential to train evaluators accordingly. For this purpose, both schools and external evaluators should be provided with transparent and accurate tools;

7. It is purposeful to set the mechanisms for encouraging most effective schools;

8. The new model of school evaluation may include use of such instruments, as publication of school performance measures and the results of external school evaluation; 
9. The model based on measuring the school effectiveness at the same time will enable the general education system to find out what is going on in public schools of the country, plan the policy of improving quality of general education.

\section{References}

Balci, A. (2011). Effective school development theory practice and research (5th edition). Pegem Academy Publications, Ankara.

Education management information system of Georgia. (2020). General Educational Institutions. Retrieved from https://www.emis.ge/Saganmanatleblo_dacesebulebebi_da_programebi/zogadsaganamanatleblo/

European Commission. (2018). Quality assurance for school development. Retrieved from https://ec.europa.eu/education/resources-and-tools/document-library/quality-assurance-for-school-development_en

Eurydice. (2020). Assuring Quality in Education: Policies and Approaches to School Evaluation in Europe. Retrieved from https://www.educationforallinindia.com/2015\%20Eurydice\%20Assuring\%20Quality\%20in\%20Edn.pdf

Frederick, J. M. (1987). Measuring School Effectiveness: Guidelines for Educational Practitioners. ERIC Information Analysis Products.

Goldstein, H. (1997). Methods in School Effectiveness Research. School Effectiveness and School Improvement, 8(4), 369-395. https://doi.org/10.1080/0924345970080401

İzzet, D. (2013). Some Model Suggestions for Measuring Effective Schools. Procedia - Social and Behavioral Sciences, 116, 1454 - 1458. https://doi.org/10.1016/j.sbspro.2014.01.415

Ministry of Education and Science of Georgia. (2005). Law of Georgia on General Education. Retrieved from https://matsne.gov.ge/en/document/view/29248?publication=68

Ministry of Education and Science of Georgia. (2007). Consolidated Education Strategy and Action Plan (2007-2011); Retrieved

from https://www.globalpartnership.org/content/georgia-consolidated-education-strategy-and-action-plan-2007-2011

Ministry of Education and Science of Georgia. (2010). Law of Georgia on General Education. Retrieved from https://matsne.gov.ge/en/document/view/29248?publication=68

Ministry of Education and Science of Georgia. (2017). Unified Strategy for Education and Science for 2017-2021. Retrieved from https://mes.gov.ge/content.php?id=7755\&lang=eng

Namchevadze, B. (2018). We Spend More and More on Low Quality School Education. Policy Document prepared by Transparency International Georgia. Retrieved from https://www.transparency.ge/sites/default/files/we_spend_more_and_more_on_low_quality_school_education.pdf

National Assessment and Evaluation Center [NAEC]. (2020). Student assessment International PISA program Georgia Report. Retrieved from https://naec.ge/uploads/postData/KVLEVEBI/PISA-2015-angarishi.pdf

National Education Accreditation Center. (2008). Annual Report. Retrieved from https://eqe.ge/res/docs/2014120814221961283.pdf)

National Center for Education Quality Enhancement. Authorization Standards for General Education Institutions. Retrieved from https://eqe.ge/eng/static/495

National Statistics Office of Georgia. (2020). Distribution of Public General School Pupils by Grade. Retrieved from https://www.geostat.ge/en/modules/categories/59/general-education

National Statistics Office of Georgia. (2020). Number of General Educational Schools. Retrieved from https://www.geostat.ge/en/modules/categories/59/general-education

Organization for Economic Co-operation and Development [OECD]. (2013). Synergies for Better Learning - an international perspective on evaluation and assessment. Retrieved from http://www.oecd.org/education/school/Synergies\%20for\%20Better\%20Learning_Summary.pdf

Organization for Economic Cooperation and Development [OECD]. (2013). School Evaluation from Compliancy to Quality.

Retrieved

from https://www.oecd-ilibrary.org/docserver/9789264190658-10-en.pdf?expires=1589369723\&id=id\&accname=guest \&checksum=3BB90B8EF36CE3C5C34C72B0F685B4A5

Organization for Economic Cooperation and Development [OECD]. (2018). Georgia, Student performance, PISA 2018. Retrieved

from 
https://gpseducation.oecd.org/CountryProfile?plotter=h5\&primaryCountry=GEO\&treshold=10\&topic=PI

Public Defender of Georgia. (2018). Situation on Human Rights and Freedoms in Georgia. Retrieved from http://www.ombudsman.ge/res/docs/2019062409381039906.pdf

Publications Office of the EU. (2018). Better learning for Europe's young people: developing coherent quality assurance strategies for school education. https://op.europa.eu/en/publication-detail/-/publication/1361c84b-80c8-11e8-ac6a-01aa75ed71a1

Publication Office of European Union. (2015). Comparative Study on Quality Assurance in EU School Education Systems - Policies, procedures and practices. Retrieved from https://www.educationforallinindia.com/2015\%20Eurydice\%20Assuring\%20Quality\%20in\%20Edn.pdf

Reagle, C. (2006). Creating Effective Schools Where All Students Can Learn. The Rural Educator, 27(3), 24-33. https://doi.org/10.35608/ruraled.v27i3.491

Ruochen, R. L., Kitchen, H., George, B., Richardson, M., \& Fordham, E. (2019). OECD Reviews of Evaluation and Assessment in Education . Retrieved from https://www.oecd-ilibrary.org/docserver/94dc370e-en.pdf?expires=1588347871\&id=id\&accname=guest\&checksu $\mathrm{m}=4 \mathrm{~A} 0 \mathrm{D} 32 \mathrm{BA} 266 \mathrm{~A} 5323716252925531 \mathrm{C} 831$

Scheerens, J. (2000). Improving school effectiveness. UNESCO International Institute for Educational Planning. ISBN (Print) 9280312049

Soung, B. (2018). Redesigning systems of school accountability: A multiple measures approach to accountability and support. Education Policy Analysis Archives, 26(8). https://doi.org/10.14507/epaa.26.2920

Wallin, J. (2003). Improving School Effectiveness. Retrieved from https://www.researchgate.net/publication/323278240

Whitby, K. (2010). School Inspection: recent experiences in high performing education system. Retrieved from https://www.educationdevelopmenttrust.com/EducationDevelopmentTrust/files/b5/b5760d3f-93ba-40dc-86f1-2e2 $32 \mathrm{df} 47 \mathrm{ce} 6 . \mathrm{pdf}$

\section{Copyrights}

Copyright for this article is retained by the author(s), with first publication rights granted to the journal.

This is an open-access article distributed under the terms and conditions of the Creative Commons Attribution license (http://creativecommons.org/licenses/by/4.0/). 